Swarthmore College

Works

$1-1-1995$

\title{
On Root Structure And The Destiny Of The Latin Second Conjugation
}

S. Davis

Donna Jo Napoli

Swarthmore College, dnapoli1@swarthmore.edu

Follow this and additional works at: https://works.swarthmore.edu/fac-linguistics

Part of the Linguistics Commons

Let us know how access to these works benefits you

\section{Recommended Citation}

S. Davis and Donna Jo Napoli. (1995). "On Root Structure And The Destiny Of The Latin Second Conjugation". Folia Linguistica Historica. Volume 16, Issue 1-2. 97-113. DOI: 10.1515/flih.1995.16.1-2.97 https://works.swarthmore.edu/fac-linguistics/29

This work is brought to you for free by Swarthmore College Libraries' Works. It has been accepted for inclusion in Linguistics Faculty Works by an authorized administrator of Works. For more information, please contact myworks@swarthmore.edu. 
Folia Linguistica Historica XVI/1-2 pp. 97-113

(1) Societas Linguistica Europaea

ON ROOT STRUCTURE

AND THE DESTINY OF THE LATIN SECOND CONJUGATION

STUART DAVIS

DONNA JO NAPOLI

\section{The issue}

Latin had four (morphological) conjugation classes of verbs, distinguished in the infinitive form by their theme vowel: the first with [a:] (clamáre 'to call'), the sccond, and numerically smallest, with [e:] (vidére 'to see'), the third with [c] (spargere 'to scatter'), and the fourth with [i:] (veni:re 'to come'). The second and third conjugation infinitives differed both by the length of their theme vowel and by the placement of primary stress (since stress placement was quantity-sensitive). When distinctive vowel length was lost in the passage from Latin to the Romance languages, the second and third conjugation infinitives were distinguished only by the placement of stress. Today, while the modern Romance languages (with the exception of Spanish and Portuguese) have maintained a special conjugation class (we call it the Special Class) for a small number of verbs from the historical second conjugation, most of the verbs of the historical second switched conjugation class, going primarily (but not exclusively) into the same class as descendants of the historical third conjugation.

In this paper we compare two competing accounts of why cerlain verbs stayed in the Special Class and others switched conjugation classes, concluding in favor of the first. We do not consider verbs that were lost in the passage from Latin into Romance.

\section{A templatic account}

In previous work (Davis - Napoli 1990, 1994), we argue that the primary factor influencing whether a verb stayed in the Special Class or not was the phonological shape of the verb root. In particular, we argue that the template in (1) was imposed upon the root structure of the descendants of historical sccond conjugation verbs, and only those roots that matched the template were candidates for staying in the Special Class (although not all verbs that were candidates for the Special Class did stay there).

(1) Template for the root structure of the Special Class: $\sigma_{\mu}$

Condition: [+ consonantal] sonorants cannot occur in the onset 
The template states that for a verb to survive in the Special Class its root must be monosyllabic. Furthermore, the root syllable must be monomoraic and not contain a sonorant consonant (although it may contain a glide) in its onset. Throughout this paper we illustrate the application of the template with the Romance infinitival form. Since the template applies to the Romance descendant (over time, gradually winnowing out the Special Class) and not to the Latin ancestor, the structure of the root syllable of the Latin ancestor is not dircctly relevant. In particular, the length of the nucleus of the root syllable of the Latin ancestor (where vowel length was distinctive) is not pertinent.

Looking at Italian, for example, we can easily see the effects of the template with regard to syllable weight. We recognize verbs in the Special Class in Italian by the fact that their theme vowel in the infinitival form is [é]. Hcre are two Italian verbs with their Latin ancestors in capitals. Dots indicate syllable breaks:

(2) do.lé.re (< DOLÉ:RE)

(3) pćn.de.re (< PENDÉ:RE)

The root syllable in (2) (do) is monomoraic, so this verb was a candidate for staying in the Special Class and it did (as seen by the fact that the theme vowel $e$ receives primary stress). Notice that the root is actually $\mathrm{dol}$. Since virtually all relevant suffixes are like the infinitive in being vowelinitial, the final root consonant does not normally syllabify with the roo vowcl; hence the root syllable of CVC roots counts as monomoraic for the template in (1).

The root syllable in (3) (pen), on the other hand, is bimoraic (since it ends with a consonant), so this verb was forced to switch into another conjugation class (and in the example in (3) the root vowel, rather than the theme vowel, receives the primary stress). Again, there is a discrepancy between the root and the root syllable. The root here is pend. And, without exception, the root syllable of CVCC roots counts as bimoraic for the template in (1).

In (4)-(5) we give several examples of Latin second conjugation verbs whose roots ended in two consonants, and their descendants in modern Italian. (+ indicates that the verb in modern Italian is archaic.) As shown in (4)-(5), all either end up with stress on the root vowel of the modern Italian infinitive instead of on the theme vowel (and so look like they descend from the Latin third conjugation - as in (4)), or they end up in the -ire class (and so look like they descend from the Latin fourth conjugation - as in (5)).

(4) árdere < ARDÉ:RE ('burn')

eccéllere < EXCELLÉ:RE ('excell') férvere < FERVÉ:RE ('be boiling hot')

fúlgere < FULGÉ:RE ('flash')

indúlgere < INDULGÉ:RE ('indulge')

méscere < MISCÉ:RE ('mix')

mólcere < MULCÉ:RE ('soothe')

mórdere < MORDÉ:RE ('bite')

múngere < MULGÉ:RE ('milk')

péndere < PENDÉ:RE ('hang')

splendere < SPLENDÉ:RE ('shine')

(ri)spóndere < (RE)SPONDÉ:RE ('to reply')

térgere < TERGÉ:RE ('wipe')

tóndere < TONDÉ:RE ('shave')

tórcere < TORQUÉ:RE ('twist')

árgere < URGÉ:RE ('urge')

+ prándere < PRANDÉ:RE ('dine')

+ tórpere < TORPE:RE ('be sluggish')

+ túrgere < TURGÉ:RE ('swell up')

(5) ardire < ARDÉ:RE ('dare')

candire < CANDÉ:RE ('whiten')

censire $<$ CENSÉ:RE ('take a census')

(ab)orrire < (AB)HORRÉ:RE ('abhor')

languire < LANGUÉ:RE ('languish')

marcire < MARCÉ:RE ('rot')

sorbire < SORBÉ:RE ('sip')

+ terrire < TERRÉ:RE ('frighten')

On the other hand, Latin second conjugation verbs whose roots ended in a single consonant (and whose root syllables were therefore monomoraic) did not normally switch conjugation classes as they passed into Italian, although a few did. This is seen by the data in (6), which includes almost the complete Special Class of Italian. (We have omitted a few verbs whose exceptional behavior is discussed in Davis - Napoli 1994 (hereafter $D \& N$ ), where those exceptions have to do with sonorant consonants in the onset of the root syllable rather than syllable weight. Two of them appear in other lists below - see (14) and (33).)

(6) avere < HABE:RE ('have')

calére < CALÉ:RE ('be warm')

dolére < DOLÉ:RE ('hurt')

dovére < DE:BÉ:RE ('must')

giacére < IACÉ:RE ('lie down')

godére < GAUDE:RE ('enjoy')

parére < PA:RÉ:RE ('seem')

persuadére < (PER)SUADÉ:RE ('persuade') 
potere < *POTÉ:RE ('can')

sedére < SEDE:RE ('sit')

solére < SOLÉ:RE ('be accustomed')

tacére < TACÉ:RE ('be silent')

temére < TIMÉ:RE ('fear')

tenćre < TENÉ:RE ('hold')

valére < VALÉ:RE ('be worth')

vedére < VIDÉ:RE ('see')

volére < *VOLÉ:RE ('want')

One type of apparent exception is seen in verbs that switched into the ire conjugation, such as:

(7) adibire < (AD)HIBÉ:RE ('adapt')

chiarire < CLA:RÉ:RE ('clear up')

fiorire < FLO:RÉ:RE ('(lower')

stupire < STUPE:RE ('astonish')

+ putire < PU:TÉ:RE ('stink')

The root syllable of all these verbs conforms to the template in (1), thus their conjugation shift at first looks unmotivated. However, all of them make use of the inchoative affix -isc in Italian (-ESC in Latin). In D\&N we show that the use of the inchoative affix was a strong factor in influencing which verbs of the Latin second conjugation went into the Italian -ire conjugation class (which is largely characterized by verbs that have the inchoative affix). We argued that this might be because the inchoative affix was reanalyzed as part of the root, thus making the root of the verb be polysyllabic and, hence, not conform to the template in (1).

The templatic account is most clearly supportcd by Italian, but as we show in D\&N, it is supported to various degrees by all the other Romance languages (although the evidence is obscured in Spanish and Portuguese, where it can be argued that the Special Class conflated with another conjugation class in the very early history of these languages). Thus verbs whose roots ended in two consonants have all swilched conjugation classes in their passage into the Romance languages of Italian, Romanian, French, Modern Occitan (also called Provençal), Catalan, and the Racto-Romance dialects. Consider, for example, the Latin second conjugation verb TON$D E ́: R E$ ('to shear'). The expected development of this Latin second conjugation verb into ltalian would be tondére. However, in Italian the verb is tóndere (which means that it has the same stress pattern we expect of descendants of the Latin third conjugation). Similarly, in the passage of Latin into Romanian, the expected development of this Latin second conjugation verb is tundéa. However the actual form of the verb in Romanian is tinde (the form we would cxpect if the ancestor was a third conjugation verb). In French, Modern Occitan, and Catalan, this Latin verb is realized as tondre (again, the form we would expect if the ancestor was a third conjugation verb). Similar data obtain throughout Romance.

Turning to the effects of the template with regard to a sonorant consonant in the onset of the root syllable, in D\&N we note that most Latin second conjugation verbs whose roots ended in a single consonant but contained a sonorant consonant in syllable onset position switched conjugation classes, although there were a few exceptions (discussed at length in Davis - Napoli 1994). We exemplify with Italian verbs:

(8) frémere < FREMÉ:RE ('shiver')

muóvere < MOVÉ:RE ('move')

nuócere < NOCÉ:RE ('harm')

rídere $<$ RI:DÉ:RE ('laugh')

strídere < STRI:DÉ:RE ('rasp')

+ lúcere < LU:CÉ:RE ('be light')

(The voiceless final affricate of the root of nuocere and of the archaic verb +lucere is not taken as long in $D \& N$, hence we place it on this list rather than (4) above.)

Again, this same effect is found throughout Romance. Thus the Romanian descent of Latin RIDÉE:RE is ride; the descendant in French and Modern Occitan is rire; the descendant in Catalan is riture - all being what we would expect if the Latin ancestor had been in the third conjugation, not the second.

In sum, the evidence in D\&N made a strong case that the shape of the root structure determined whether a historic Latin second conjugation verb could remain in the Special Class or was forced to switch classes over time across Romance.

3. The perfect form as key

An alternative account of the determination of which verbs stay in the Special Class looks crucially at the perfect form of the Latin verb.

Recently, Mester (1994) has discussed the allomorphy patterns found in the perfect formation of Latin second conjugation verbs. Mester observes that most Latin second conjugation verbs having a monomoraic root syllable formed their perfect by the suffixing of $-t u$, the so-called $\mathrm{u}-$ perfect, while other Latin sccond conjugation verbs formed their perfect either by the suffixation of $-s$ (the s-perfect) or by reduplication. (He does not mention other, less frequently found, ways of forming the perfect.)

Given Mester's finding, one might hypothesize that what determines whether a Latin second conjugation verb switches conjugation classes as it passes into a daughter language, say Italian, is the character of its perfect form: 
(9) Perfect-form Hypothesis:

If the verb took the u-perfect, it could stay in the Special

Class. If the verb took the s-perfect or the reduplicative per-

fect, it had to switch conjugation classes.

Indeed, Malkiel (undated) claims that the form of the perfect is important in determining other instances of conjugation class switch from Latin into Romance, thus the hypothesis in (9) would not be without precedent.

We state (9) in tcrms of identifying candidates for the Special Class, rather than in terms of identifying roots that had to stay in the Special Class, both so that the proposal in (9) is comparable to the proposal in (1) and because the untenability of the alternative proposal is immediate (as is easily seen when we discuss the data in (12)-(13) below).

4. A comparison of empirical adequacy

In the remainder of this paper we defend the templatic account over the perfect-form account, arguing in this section that the former is superior with respect to empirical adequacy and in the next section that the former is superior with respect to theoretical soundness. We demonstrate with data from Italian, but similar demonstrations could be made using data from the other Romance languages.

The similarities in (1) and (9) are significant. (1) claims that the form of the root syllable of the descendant verb is directly relevant. (9) claims that only the form of the perfect is relevant. However, if we take all of Mesters work into consideration, the form of the root syllable of the Latin verb (not the descendant verb) is indirectly relevant with the proposal in (9), since this form determines whether or not a verb will take the u-perfect. Whenever both the Latin verb and its descendant have a monomoraic root syllable without a sonorant consonant in the onset of the root syllable of the descendant verb and, additionally, the Latin verb takes the un-perfect, both proposals predict that the descendant will be a candidate for the Special Class. Whenever both the Latin verb and its descendant have a bimoraic root syllable and the Latin verb takes the s-perfect or the reduplicative perfect, both proposals predict that the descendant will switch conjugation classes. These two situations cover most of the relevant verbs, thus the two proposals fare equally well for the majority of the data.

Indeed, most (ten out of seventeen) of the Latin second conjugation verbs in (6) (including the reconstructed but unattested *POTE:RE and *VOLÉ:RE), all of whose descendants stay in the Special Class, both take the u-perfect and have a root syllable that is monomoraic in both the Latin and the descendant verb and the root syllable of the descendant verb has no sonorant consonant in the onset. (The [h] of $H A B E: R E$, a sonorant, was lost in the passage to Italian avére.) This is shown in (10). (The final /i:/ is the first person singular suffix.)

(10) HABÉ:RE hab-u-i:

CALÉ:RE cal-u-i:

DOLÉ:RE dol-u-i:

*POTÉ:RE pot-u-i:

SOLÉ:RE sol-u-i:

TACÉ:RE tac-u-i:

TENÉ:RE ten-u-i:

TENÉ:RE ten-u-i:

VALE:RE val-u-i:

VOLÉ:RE vol-u-i:

(We give no glosses in (10) since these verbs all appeared in (6) above. In the rest of this paper we give an English gloss for only those Latin and Italian verbs that appear for the first time.)

Also, most of the verbs in (4) (fourteen out of twenty), which have a bimoraic root in both Latin and the descendant verb, take an s-perfect or a reduplicated perfect. And these verbs changed conjugation classes, as predicted by both proposals.

(11) ARDÉ:RE arsi;

FULGE:RE fulsi:

INDULGE:RE indulsi:

LU:GÉ:RE luxi:

MULCÉ:RE mulsi:

MULGÉ:RE mulsi:

MORDE:RE momordi:

PENDÉ:RE pependi:

(RE)SPONDÉ:RE spopondi:

TERGE:RE tersi:

TONDÉ:RE totondi:

TORQUÉ:RE torsi:

TURGÉ:RE tursi:

URGÉ:RE ursi:

(We take the orthographic $x$ of luxi to indicate [ks], as in Tagliavini 1969: 245.)

However, the differences between (1) and (9) are also significant. Indeed, if we consider only the perfect form and not the form of the root syllable in Latin (that is, if we consider only (9) as stated and not the correlation between perfect form and root-syllable form that Mester re- 
vealed), the two proposals are quite different. And now the templatic account emerges as supcrior.

The following Latin second conjugation verbs use the u-perfect, but their descendants do not stay in the Special Class, instead going into the conjugation class we would expect for descendants of the third conjugation (in (12)) or for descendants of the fourth conjugation (in (13)).

(12) eccéllere < EXCELLÉ:RE excell-u-i:

férvere < FERVE:RE ferb-u-i:

frćmere < FREME:RE frem-u-i:

méscere < MISCÉ:R misc-uni:

nuócere < NOCE:RE noc-u-i:

spléndcre < SPLENDÉ:RE splend-u-i:

+ pátere < PATÉ:RE pat-u-i: ('be clear')

+ tépere < TEPÉ:RE tep-u-i: ('be warm')

+ tórpere < TORPÉ:RE torp-u-i:

+ vígere < VIGÉ:RE vig-u-i: ('be vigorous')

(13) adibirc < (AD)HIBÉ:RE adhib-u-i: ('adapt')

candire < CANDÉ:RE cand-u-i: ('whiten')

censire < CE:NSÉ:RE ce:ns-u-i: ('take a census')

chiarire < CLA:RÉ:RE cla:r-u-i: ("clear up')

fiorire < FLO:RÉ:RE flo:r-u-i: ('flower')

aborrire < HORRE:RE horr-u-i: ('abhor')

languire < LANGUÉ:RE lang-u-i: ('languish')

ammonire < (AD)MONÉ:RE (ad)mon-u-i: ('warn')

+ aulire < (OLÉ:RE ol-u-i: ('smell good')

pentirsi < (PAE)NITÉ:RE (pae)nit-u-i: ('repent')

t putire < PU:TÉ:RE pu:t-u-i: ('stink')

assorbire < SORBÉ:RE sorb-u-i: ('absorb')

stupire < STUPÉ:RE stup-u-i: ('astonish')

atterrire < TERRÉ:RE terr-u-i: ('frighten')

Of the ten Latin verbs in (12), the descendants of all but two of them (+patere and +tepere) have a root syllable that is either bimoraic or has a sonorant consonant in the onset (or both). (Note that mescere and + vigere have roots that end in long consonants (Chierchia 1986). And see Davis - Napoli 1994 for an extended discussion of +vigere.) Thus the templatic account predicts the conjugation switch of eight of these verbs. But the perfect-form account, while compatible with the data in (12), offers no molivation for why these verbs should have switched conjugation class.

Of the fourteen Latin verbs in (13), the descendants of all but five of them (adibire, chiarire, fiorire, putire, and stupire) have a root syllable that is either bimoraic or has a sonorant consonant in the onset (or both).
Significantly, these five verbs appear on the list in (7) above: all make use of the inchoative affix -isc and hence do not conform to the template in (1). Indeed, most of the verbs in (13) (ten out of fourteen) make use of the inchoative affix, just like many verbs of the historic fourth conjugation The templatic account, then, not only predicts the conjugation switch of all of the verbs in (13), it is suggestive of which conjugation those verbs will switch into (the -ire conjugation). That is, the templatic account points out the importance of root structure for conjugation class, thus the fact that a verbs root includes this $-i s c$ might well be a relevant factor in its membership to the -ire conjugation class. But the perfect-form account, while compatible with the data in (13), again offers no motivation for the conjugation class switch of these verbs, with the possible cxception of the verb SORBÉ:RE, which had an infrequent s"perfect (sorpsi) in addition to its u-perfect.

Additionally, the following Latin second conjugation verbs used the s-perfect but their descendants stayed in the Special Class, in direct contradiction to (9):

(14) godére < GAUDÉ:RE ga:visi:

persuadére < (PER)SUA:DÉ:RE (per)suasi:

(ri)manere < (RE)MANÉ:RE (re)mansi: ('remain')

Of these three, only the last verb is problematic for the templatic account (violating the condition against a sonorant consonant in the onset).

Also, some verbs of the Latin second conjugation formed their perfects in none of the ways mentioned in (9). Since (9) singles out the u-perfect as special, we might expect that decendants of any verb that formed its perfect in a way other than the u-perfect would not be candidates for the Special Class. However, the following verbs had such irregular perfects and their descendants stayed in the Special Class:

(15) sedére < SEDÉ:RE se:di

vedére < VIDÉ:RE vi:di

+ delére < DE:LE:RE de:le:vi: ('destroy')

+ pavére < PAVÉ:RE pa:vi: ('fear')

(The final two verbs of (15) are listed as archaic in some dictionaries, but they have been lost from the specch of the speakers we consulted.) Furthermore, one verb whose descendant stayed in the Special Class had an alternative irregular perfect:

(16) tenére TENÉ:RE ten-u-i: but also: tenivi;

We suspect, however, that the v-perfect is a variant of the u-perfect, so this might not be an irregular perfect, after all. (See Tagliavini 1969 261 for similarities between the u-perfect and the v-perfect.) 
It is true that some Latin verbs with irregular perfects (that is, perfects other than the u-perfect, the s-perfect, and the reduplicative perfect) switched conjugation classes:

(17) muóvere < MOVÉ:RE mo:vi: ('move')

cómpiere < (COM)PLE:RE comple:vi: ('fill out')

+ prándcre < PRANDÉ:RE prandi: ('dine')

stridere < STRI:DÉ:RE stri:di: ('rasp')

(18) abolire < ABOLÉ:RE abole:vi: ('abolish')

Descendants of three of the four verbs in (17), however, have a root syllable that has a sonorant consonant in the onset and, in two of them, the root syllable is bimoraic, thus the templatic account would have predicted conjugation switch for these verbs. And the conjugation switch of compiere is consistent with (though not predicted by) the templatic approach. Furthermore, the verb in (18) has a polysyllabic root, thus it does not conform to the template and should have switched conjugation classes. Indecd, this verb has a frequently found alternate u-perfect form (abol. $u-i:)$, thus its conjugation switch may not be predicted by (9) after all.

And notice that two of the five verbs in (17)-(18) have veperfects. If the v-perfect is, indeed, just a variant of the u-perfect, these verbs belong on the list in (12) and (9) would have led us to expect these roots to be candidates for the Special Class.

A last point we would like to make is that two verbs of the Latin third conjugation switched conjugation classes and wound up in the Spccial Class in Italian (and in other Romance languages). In both instances the root syllable of the descendants of these verbs conformed to the template in (1), but neither used the u-perfect (although one has an alternant v-perfect):

(19) cadcre < CADERE cecidi: ('fall')

sapére < SAPERE sapii: or: sapi:vi: ('know')

Additional differences can be found between (1) and (9) if we consider not just (9) as stated, but the correlation between perfect form and rootsyllable form that Mester revealed. Mester noted that Latin second conjugation verbs whose root syllable contained a long vowel normally took the u-perfect. Since vowcl-length distinction was lost in the Romance languages as they descended from Latin, (1) predicts that a long root vowel in the Latin verb is irrelcvant to conjugation class determination, whereas (9) predicts such a verb should take the s-perfect or the reduplicative perfect (or any perfect other than the u-perfect) and, accordingly, switch conjugation classes. In order not to duplicate our efforts above, let us here examine only those Latin verbs with a long root vowel which have a single consonant in the coda of the root (so that the root syllable in the infinitival form ends with the vowel). There are eleven such verbs to consider.

(20) rídere < RI:DÉ:RE ri:si:

strídere < STRI:DÉ:RE stri:di

+ lúcere < LU:CÉ:RE lu:xi:

+ lúgere < LU:GÉ:RE ('be in mourning') lu:xi:

(21) persuadere < (PER)SUA:DÉ:RE persua:si:

(22) chiarire < CLA:RE:RE cla:rui:

fiorire < FLO:RE:RE flo:rui:

+ putire < PU:TÉ:RE pu:tui

(23) dovére < DE:BÉ:RE de:bui:

parére < PA:RÉ:RE pa:rui:

(24) + delére < DE:LÉ:RE de:le:vi:

In (20) we find four verbs with a long root vowel in Latin that all took a perfect other than the u-perfect, as predicted by Mester. They also switched conjugation classes, as predicted by (9), so that the descendants (two of which are archaic or recently lost) look like they came from the historical third conjugation. (1) also predicts conjugation switch for these verbs, however, since all four Italian verbs have a sonorant consonant in the root syllable onset.

In (21) we find a verb with a long root vowel in Latin that does not take the u-perfect, as predicted by Mester. But this verb does not switch conjugation classes, contrary to (9). (1), in contrast, correctly identifies this verb as a candidate for the Special Class.

In (22) we find three verbs with a long root vowel in Latin that make use of the u-perfect. All three switched conjugation classes so that the descendants look like they came from the historical fourth conjugation. (9) does not predict this switch. However, these verbs are exceptions to Mesters generalization in that they don't have the expected perfect forms. Indeed, we could modify (9) to say that if a verb "should" take a perfect other than the u-perfect, it should switch conjugation classes. The modified (9) would then predict the conjugation switch here. As we noted above in discussing (13), (1) also predicts this switch, since these verbs make use of the inchoative $-i s c$ and hence are open to being reanalyzed as having a polysyllabic root. However, the two accounts are not equally interesting. With (1), the focus is on the fact that these verbs take the inchoative $-i s c$, hence their passage into precisely the -ire conjugation rather than any other conjugation is expected (as we noted above). But with the modified (9) the choice of which conjugation these verbs switch into is arbitrary.

In (23) we find two yerbs with a long root vowel in Latin that make use of the u-perfect, constituting exceptions to Mesters generalization. 
Neither switch conjugation classes. Our original (9) predicts this, but our modified (9) does not. If we opt to stay with the original (9), then all four verbs in (22) are a problem for the account of conjugation switch based on the form of the perfect. If we opt for the modified (9), then the two verbs in 23 are a problem for that account. On the other hand, (1) correctly identifies these roots as candidates for the Special Class.

Finally, in (24) we find an archaic (and, for some speakers, now lost) verb with a long root vowel in Latin that makes use of the v-perfect. This verb stayed in the Special Conjugation. If the v-perfect is a variant of the u-perfect, this verb belongs on the list in (23) and is accordingly problematic for the modified (9) but not for the original (9). If the v-perfect is distinct from the u-perfect, this verb belongs on the list in (21) and is problematic for (9). In either case, this verbs candidacy for the Special Class is predicted by (1).

Overall, the templatic account is empirically superior to (9) in these cases.

There is yet one more type of situation we should examine, that in which the Latin root syllable contained a diphthong. Some diphthongs in Latin were reduced in Romance to short vowels and others survived as diphthongs. Given Mesters generalization, we expect second conjugation verbs with a diphthong in the root syllable to take a perfect other than the u-perfect. (9), then, predicts these verbs would switch conjugation classes. The Romance templatic proposal in (1) predicts that only those Latin diphthongs that survived as diphthongs in the daughter will be relevant. So let us consider Latin verbs of the second conjugation whose root nucleus was a diphthong (and did not include a long yowel - since we've already discussed those verbs above) and whose root ended in a single consonant. There are only four verbs to consider.

(25) aderire < HAERÉ:RE ('adhere') haesi:

(26) godere < GAUDÉ:RE gavisi:

(27) giacére < IACÉ:RE jacui:

(28) + fetére < FOETÉ:RE ('stink')

In (25) we find a Latin verb whose root syllable contained a diphthong and whose Italian descendant does not contain a diphthong. This verb docs not take the u-perfecl, as predicted by Mester. This verb switched conjugation classes, as (9) predicts. However, this verb takes the inchoative -isc, thus (1) not only predicts conjugation switch, but suggests the choice of destination conjugation (the -ire conjugation).

In (26) we find a Latin verb whose root syllable contained a diphthong and whose Italian descendant does not contain a diphthong. This verb does not take the u-perfect, as predicted by Mester. However, it does not switch conjugation classes, violating (9). (1), on the other hand, correctly identifies this verb as a candidate for the Special Class.

In (27) we find a Latin verb whose root syllable contained a diphthong and whose Italian descendant does not contain a diphthong. This verb does take the u-perfect, so it constitutes an exception to Mesters generalization. It did not switch conjugation classes. Both (9) and (1) correctly identify this verb as a candidate for the Special Class.

In (28) we find a Latin verb whose root syllable contained a diphthong and whose Italian descendant does not contain a diphthong. This verb is archaic (and, for many speakers, lost). It stayed in the Special Class in Italian. This verb, however, lacks a perfect form. Thus (9) makes no predictions about its conjugation class, whereas (1) correctly identifies it as a candidate for the Special Class.

Again, overall, the templatic account is empirically superior to (9) in these cases.

\section{Theoretical soundness}

In Section 4 we saw that, on the whole, (1) displays greater empirical adequacy than (9). Let us now compare the two accounts as to their theoretical soundness. (1) leads us to a situation in which the child language learner considers the structure of the root syllable when assigning conjugation class. Certainly, the child always has access to this information. (9), on the other hand, leads us to a situation in which the child language learner considers the Latin perfect form when assigning conjugation class. It is quite possible that a child can make cross-word comparisons (Dresher - Kaye 1990: 171ff., Lightfoot 1991, among many others) in such a way that the form of the perfect would be decisive to conjugation choice. Furthermore, even though the root of the Latin perfect form is not identical to the root used thoughout the Latin present, future, and imperfective lenses, for example, it is again quite possible for the child to recognize the relationship between the two forms without actually deriving one form from the other (and see Aronoff 1994 for a discussion of lexemes with more than one stem). However, the particular proposal in (9) is problematic for two reasons.

First, not all Latin verbs had a perfect form. We already saw one such case, in (28) above. Others include:

(29) + ebére < HEBÉ:RE ('be dumb')

(30) marcire < MARCÉ:RE ('rot')

(9) makes no predictions about such verbs. If language learners had to rely on the perfect form in order to know the conjugation class of a verb, they would be flummoxed in such cases. (Notice that (1) correctly 
identifies the archaic verb in (29) as a candidate for the Special Class and correctly predicts that the verb in (30) will switch conjugation classes - and, furthermore, to the ire conjugation, since this verb makes use of the inchoative $-i s c$.)

Certainly a learning thcory should have a property of Robustness like that proposed in Dresher and Kaye (1990), whercby core parameters must be learnable despite various disturbances, such as exceptions. And, indecd, missing base forms are found often in morphology (Anderson 1992: 189, among others). But when the exception is a suppletive gap and the gap represents the crucial information for conjugation class choice, we expect the child to place the verb in either the productive class (in Italian the first conjugation, marked with the theme vowel $a$ ) or the largest class (in Italian the second conjugation, marked with the theme vowel and stress on the last vowel of the root). But in (28)-(30) this has not happened. The verbs in (28)-(29) have descendants in the smallest conjugation class (the Special Class) and the verb in (30) has a descendan in the next smallest class.

Second, the Latin perfect evolved into a remote past that was phonologically reduced in such a way that the $u$ of the u-perfect, by and large, was quickly lost across Romance (the obvious exception bcing Romanian, sec Tagliavini 1969: 261). For example, consider:

\section{(31) ebbi < habui '(I) had'}

dovetli < de.bui '(I) had to'

These examples are representative. Thus the remote past form could not be used by the language learner of early Romance to identify which verbs used the u-perfect in Latin. Furthermore, the Special Class lost members not in a single blow, but gradually over centuries (D\&N) Clearly, the remote past form would not have helped the language learne correctly identify the relevant verbs over those centuries or today in modern Romance.

A proponent of (9) might look to other forms in the modern languages (Crom carly times to today) to try to find information that would help to identify those verbs that used the $u$-perfect in Latin. The modern perfect at first seems like a likely candidate. Perfective aspect in the Romance languages is expressed by a periphrastic perfect that arose in Classical Latin and developed side by side with the remote past (Lausberg 1971: 220). This periphrastic form consists of an auxiliary plus a perfect participlc. The form of the Romance perfect participle, however, does not reflect the form of the Latin perfect. It is true, however, that the perfect participle for the Special Class in Italian often makes use of what could be called the u-participle, as in:
(32) avere avuto

cadere caduto

dolere doluto

dovere dovuto

giacere giaciuto

godere goduto

piacere piaciuto

potere potuto

sapere saputo

sedere seduto

tacere taciuto

temere temuto

tenere tenuto

volcre voluto

However, there are verbs of the Special Class that don't use the uparticiple, such as:

(33) + licere licito/lecito ('be allowed')

parere parso

persuadere persuaso

rimanere rimasto

solere solito

valere valso

vedere visto (but also: veduto)

And there are verbs of other conjugations that do use the u-participle. The verbs in (34) all have root stress, and the verb in (35) is in the ire conjugation:

(34) conoscere conosciuto

crescere cresciuto

devolvere devolut

nuocere nociuto

pascere pasciuto

perdere perduto (also: perso)

piovere piovuto

vivere vissuto

(35) venire venuto

Additionally, one verb of the Special Class lacks a perfect participle:

(35) calere

So the perfect participle is not a good indicator. Indeed, there does not seem to be any reliable way to identify the verbs that used the u-perfect 
in Latin from looking at the verbal forms in the daughter languages (either in early Romance or today). This is an insurmountable barrier for (9) in terms of learnability theory.

We conclude that (1) is the more theoretically sound approach.

\section{Conclusion}

Whilc the accounts of the conjugation class shift examined here often make the same prediction, given that it was usually the case that only verbs with monomoraic root syllables took the $u$-perfect, we have examined those instances in which these accounts make different predictions and shown that root structure in Romance is a better indicator of conjugation class shift than the nature of the perfect or than root structure in Latin. Given that in D\&N we already showed that templatic factors were more important than possible semantic factors in determining conjugation class shift, it seems quite evident that root structure is indeed the most important factor in determining the destiny of Latin second conjugation verbs as they passed into Romance.

\section{ACKNOWLEDGEMENTS}

We thank Stephen Stortz for assisting us in gathering data on Latin perfect forms. We thank Mark Aronoff, David Lightfoot, and Armin Mester for discussing some of the ideas here with us.

DONNA JO NAPOLI Swarthmore College SWARTHMORE, PA 19081

USA

STUART DAVIS

Department of Linguistics Indiana University Menorial Hall 322 BLOOMINGTON, IN 47405

\section{REFERENCES}

Anderson, Sicphen

1992 A-morphous morphology. Cambridge: Cambridge University Press. Aronoff, Mark

1994 Morphology by itself. Cambridge, MA: MIT Press.

Chicrchia, Gennaro

1986 "Length, syllabification and the phonological cycle in Italian", Joumal of Ital"Length, syllabitication
Davis, Stuart - Donna Jo Napoli

1990 "The destiny of Latin sccond conjugation infinitives in Romance", Probus 2. 125-166.

1994 A prosodic template in historical change: The passage of the Latin second conjugation into Romance. Torino: Rosenberg \& Sellier.

Dresher, Elan - Jonathan Kaye

1990 "A computational learning modcl for metrical phonology", Cognition 34: 137195.

Lausberg, Heinrich

1971 Linguistica romanza II. morfologia. Milano: Feltinelli Editore.

Lightfoot, David

1991 How to set parameters: Arguments from language change. Cambridge, MA MIT Press.

Malkiel, Yakov

no date Outline: Reassignment of verbs to conjugation classes in Early Romance. [Unpublished MS, University of California at Berkeley.]

Mester, R. Armin

1994 "The quantitative trochee in Latin", Natural Language and Linguistic Theory $12,1: 1-62$.

Tagliavini, Carlo

1969 Le origini delle lingue neolatine. Bologna: Casa Editrice Prof. Riccardo Pàtron. 